\title{
APAKAH KPH DAPAT MEMPERBAIKI TATA KELOLA HUTAN INDONESIA?
}

\author{
Eno Suwarno \\ Staf pengajar Fakultas Kehutanan Universitas Lancang Kuning \\ Jl. Yos Sudarso Km. 8 Rumbai Pekanbaru \\ Telp./Fax. (0761) 54092 \\ E-mail: enosuwarno@gmail.com
}

\begin{abstract}
Since the early 2000s, Forestry Department of Indonesia has been implementing the Forest Management Unit (FMU) development program. The existence of FMU can be seen as a prerequisite for the implementation of sustainable forest management and equitable. How FMU institution prospects can improve forest governance in Indonesia? The aim of this study is to explore the prospects of FMU institution to improve forest governance in Indonesia. The study used forestry governance dimensions of Mayers and Macqueen (2002) as an analytical tool. The study results showed that both conceptual and is based on the processes of development, FMU has accommodated most of the values of good forestry governance.
\end{abstract}

Keywords: forest management unit, institutions, fosretry governance 


\section{PENDAHULUAN}

Ditinjau dari perspektif ilmu kelembagaan, kerusakan hutan Indonesia di luar Pulau Jawa pada umumnya karena tidak adanya organisasi pengelola di tingkat tapak. Situasi demikian menyebabkan pada sebagian kawasan hutan negara secara de facto menjadi sumberdaya open access.

Praktek-praktek penebangan liar dan perambahan hutan menyebabkan terjadinya deforestasi dan degradasi hutan (Kartodihardjo et al, 2011). Kondisi open access ini akibat lemahnya pengelolaan hutan oleh pemerintah dan pemegang ijin usaha yang lebih berorientasi kepada mengeksploitasi komoditi kayu, bukan berorientasi kepada pengelolaan kawasan hutan (ICCON 2006). Menurut Pratikno (2005), lemahnya tata kelola (governance) adalah penyebab umum terjadinya kegagalan pembangunan negara-negara di dunia, sebagaimana dinyatakan
Bank Dunia pada tahun 1989 dalam laporannya yang sangat terkenal "Sub-Saharan Africa: From Crisis to Sustainable Growth". Dalam laporan ini dinyatakan bahwa tata kelola yang buruk (bad governance) menjadi sumber kegagalan pembangunan di negara-negara Sub-Sahara Afrika.

Untuk mengatasi

permasalahan tersebut, Departemen Kehutanan sejak awal tahun 2000-an telah menggulirkan program pembangunan Kesatuan Pengelolaan Hutan (KPH). Keberadaan KPH dapat dipandang sebagai prasyarat terselenggaranya pengelolaan hutan berkelanjutan dan berkeadilan (Kartodihardjo et al. 2011). Pertanyaannya adalah bagaimana prospek kelembagaan $\mathrm{KPH}$ dalam memperbaiki tata kelola hutan Indonesia ditinjau dari perspektif good forestry governance? Tujuan penulisan 
paper ini adalah untuk mengkaji prospek kelembagaan KPH dalam memperbaiki tata kelola hutan di Indonesia. Kajian ini menggunakan dimensi-dimensi forestry governance dari Mayers dan Macqueen (2002) sebagai alat analisis.

\section{TATA KELOLA HUTAN}

\section{Pengertian Tata Kelola Hutan (Forestry Governance) dan Ciri-Cirinya}

Menurut AusAID (2000), governance adalah penggunaan kekuasaan atau otoritas - politis, ekonomi, administratif, dan lainlain - untuk mengelola sumbersumber daya dan hubunganhubungan di dalam negara. la meliputi mekanisme, proses dan institusi dimana pemerintah, warga negara serta kelompok masyarakat mengartikulasikan kepentingan mereka, menggunakan hak hukum yang sesuai dengan kewajiban mereka, dan memediasi perbedaanperbedaan di antara mereka.
Bank Dunia

(2009)

menyatakan bahwa governance dikatakan "baik" ketika dapat mengalokasikan dan mengelola sumber-sumber daya secara efisien, efektif, dan pantas. Good governance ditandai dengan sikap menghormati kepastian hukum, transparansi dan aliran informasi yang bebas, keikutsertaan warga negara yang signifikan, kesetaraan, akuntabilitas yang tinggi, manajemen sumbersumber daya publik yang efektif, dan pengendalian terhadap korupsi.

Sejalan dengan good governance, good forest governance ditandai dengan adanya kepastian hukum, tingkat korupsi yang rendah, institusi yang sehat dan kuat, kompetensi aparat yang tinggi, kesediaan untuk menghadapi isu-isu kehutanan, ketulusan dalam mengatur unsur-unsur hukum yang kritis seperti property right, dan lain-lain. Sedangkan poor 
forest governance akan memberikan dampak negatif secara nyata kepada tiga pilar tujuan pembangunan kehutanan, yaitu pada: pembangunan lingkungan, pengurangan kemiskinan dan pembangunan sosial, serta pertumbuhan ekonomi (Bank Dunia, 2009).

Dimensi-Dimensi Kelembagaan Tata Kelola Hutan

Governance pada dasarnya adalah suatu tatanan kelembagaan untuk mencapai tujuan yang melibatkan para aktor melalui mekanisme inter-relasi yang dikontrol dengan instrumen pengontrol mekanisme. Outcome yang diharapkan adalah hutan lestari dan rakyat sejahtera (Mayers dan Macqueen, 2002). Rincian mekanisme inter-relasi dan instrumen pengontrolnya sebagai sistem dasar dari good forestry governance adalah: informasi (akses, cakupan, kualitas, $\quad$ transparansi); mekanisme

partisipasi

(keterwakilan, kesempatan yang sama, akses); keuangan (internalisasi eksternalitas, efisiensi biaya); keahlian (efisiensi dan keadilan dalam membangun modal sosial dan modal sumberdaya manusia), dan; proses perencanaan dan pengelolaan (pengaturan prioritas, pengambilan keputusan, koordinasi dan akuntabilitas).

\section{KONSEPSI KPH}

Pengertian KPH sebagai suatu unit pengelolaan hutan secara formal mulai muncul di dalam Undang-Undang Nomor 41 tahun 1999 tentang Kehutanan, yaitu pada penjelasan dari pasal 17: "Yang dimaksud dengan unit pengelolaan adalah kesatuan pengelolaan hutan terkecil sesuai fungsi pokok dan peruntukannya, yang dapat dikelola secara efisien dan lestari. Menurut Peraturan Pemerintah Nomor 6 tahun 2007, Kesatuan Pengelolaan Hutan 
selanjutnya disingkat $\mathrm{KPH}$ adalah wilayah pengelolaan hutan sesuai fungsi pokok dan peruntukannya yang dapat dikelola secara efisien dan lestari. $\mathrm{KPH}$ meliputi $\mathrm{KPH}$ Konservasi (KPHK), KPH Lindung (KPHL), dan KPH Produksi (KPHP). Menurut Keputusan Menteri Kehutanan Nomor P.6 Tahun 2009, KPHK adalah KPH yang luas wilayahnya seluruhnya atau didominasi oleh kawasan hutan konservasi, KPHL adalah $\mathrm{KPH}$ yang luas wilayahnya seluruhnya atau didominasi oleh kawasan hutan lindung, dan $\mathrm{KPHP}$ adalah $\mathrm{KPH}$ yang luas wilayahnya seluruhnya atau didominasi oleh kawasan hutan produksi.

Organisasi dan tupoksi organisasi $\mathrm{KPH}$ merujuk kepada Peraturan Pemerintah Nomor 6 tahun 2007. Setiap wilayah $\mathrm{KPH}$ akan dikelola oleh organisasi pengelola $\mathrm{KPH}$ yang merupakan organisasi di tingkat tapak. Organisasi KPHK merupakan organisasi perangkat pusat, organisasi KPHL dan KPHP merupakan organisasi perangkat daerah.

Menurut

Peraturan

Pemerintah PP Nomor 6 Tahun 2007, organisasi KPH mempunyai tugas dan fungsi :

menyelenggarakan pengelolaan hutan yang meliputi tata hutan dan penyusunan rencana pengelolaan hutan, pemanfaatan hutan, penggunaan kawasan hutan, rehabilitasi hutan dan reklamasi, perlindungan hutan dan konservasi alam; (b) menjabarkan kebijakan kehutanan nasional, provinsi dan kabupaten/kota bidang kehutanan untuk diimplementasikan;

melaksanakan

kegiatan pengelolaan hutan di wilayahnya mulai dari perencanaan, pengorganisasian, pelaksanaan dan pengawasan serta pengendalian; (d) melaksanakan pemantauan dan penilaian atas 
pelaksanaan

kegiatan

pengelolaan hutan di wilayahnya;

dan (e) membuka peluang investasi guna mendukung tercapainya tujuan pengelolaan hutan.

\section{METODE}

Kajian dalam tulisan ini menggunakan kerangka analisis dimensi-dimensi forestry governance dari Mayers dan Macqueen (2002). Dari bentuk analisis kebijakan menggunakan analisis integratif yang mengkombinasikan

analisis prospektif (eks-ante) dan analisis restropektif (eks-post) (lihat Dunn, 2000).

Adapun rincian mekanisme inter-relasi dan instrumen pengontrol mekanisme interrelasi yang digunakan dalam kajian ini adalah sebagai berikut:

1. Kejelasan peran dan kewenangan: tata hubungan kerja
2. Keuangan: pembagian biaya dan penghasilan

3. Partisipasi:

aturan keterwakilan

4. Informasi: masalah akses, cakupan, kualitas, dan transparansi informasi.

5. Keahlian: keadilan dan efisiensi dalam pembangunan modal sosial dan modal sumberdaya manusia.

6. Proses perencanaan dan pengelolaan: penetapan prioritas, pembuatan keputusan, koordinasi, dan umpan balik perbaikan.

Kajian kelembagaan $\mathrm{KPH}$ akan dilakukan pada tataran konsepsi $\mathrm{KPH}$ dan pada tataran proses-proses implementasinya yang sedang berlangsung.

\section{ANALISIS KELEMBAGAAN $\mathrm{KPH}$}

1. Kejelasan peran dan kewenangan: ada tata hubungan kerja 
Berdasarkan Pemraturan Kota) menyelenggarakan fungsi Pemerintah Nomor 6 Tahun 2007 pengurusan hutan. Bagan posisi organisasi $\mathrm{KPH}$ dan matrik pembagian kegiatan menyelenggarakan fungsi dapat dilihat pada gambar berikut. managemen atau pengelolaan hutan, sedangkan instansi struktural pemerintah (Kemenhut, Dinas Kehutanan Provinsi/Kab/

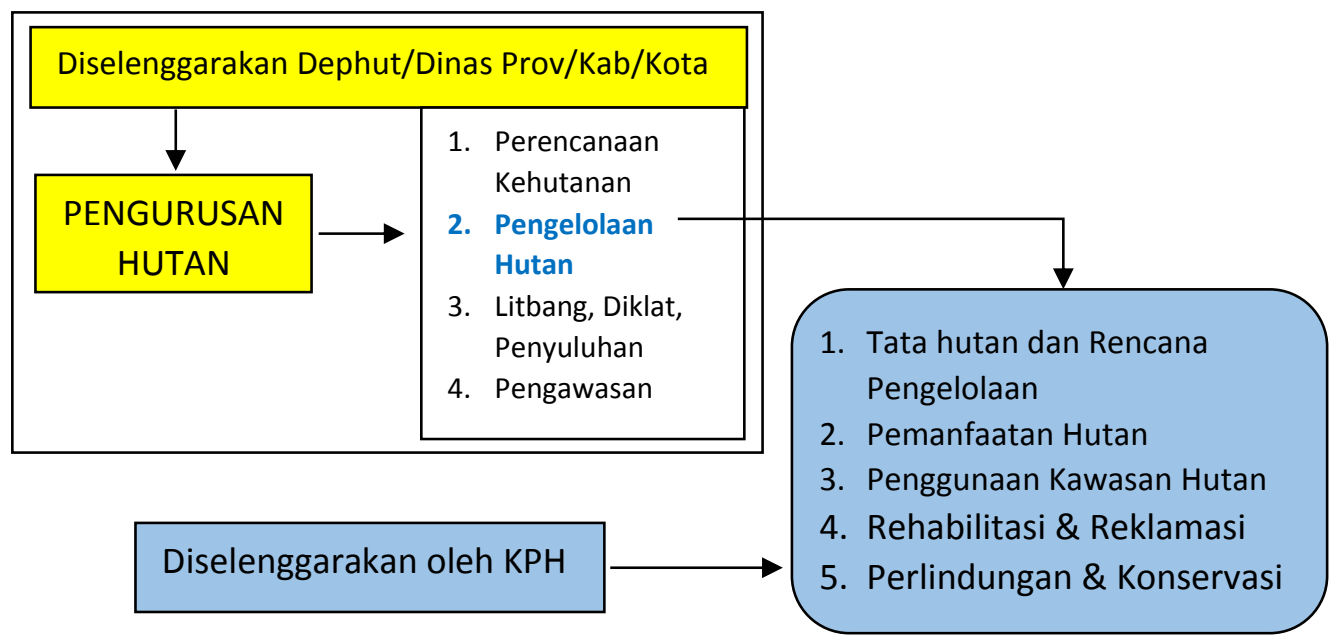

Gambar 1. Posisi pengurusan dan pengelolaan hutan (Dirplanhut, 2009) 
Tujuan utama dibangunnya $\mathrm{KPH}$ adalah untuk mengisi kekosongan atau memperkuat pengelolaan hutan di tingkat tapak. Kegiatan-kegiatan utama $\mathrm{KPH}$ mencakup tata hutan dan penyusunan rencaa pengelolaan hutan, pemanfaatan hutan, penggunaan kawasan hutan, rehabilitas, perlindungan dan konservasi. Dengan demikian maka secara konseptual $\mathrm{KPH}$ menunjukan adanya kejelasan pembagian peran dan kewenangan sebagaimana ditunjukan pada Gambar 1. Instrumen pengontrol mekanisme interrelasi yang sudah dapat diidentifikasi adalah adanya tata hubungan kerja, sedangkan instrumen lainnya baru akan nampak bila $\mathrm{KPH}$ sudah operasional.

1. Keuangan: pembagian biaya dan penghasilan

\section{Menurut}

Peraturan

Pemerintah Nomor 6 Tahun 2007, dana pembangunan $\mathrm{KPH}$ bersumber dari APBN, APBD, dan/atau dana lain yang tidak mengikat sesuai ketentuan peraturan perundang-undangan. Adapun penghasilan dari hutan menurut pasal 79 dapat berupa IIUPH; PSDH; DR; dana hasil usaha penjualan tegakan; pungutan dari pengusahaan pariwisata alam; penerimaan dari pungutan kunjungan wisata ke kawasan hutan wisata, taman nasional, taman hutan raya dan taman wisata laut; iuran pengambilan/penangkapan dan pengangkutan satwa liar dan tumbuhan alam yang tidak dilindungi undang-undang serta jarahan satwa buru; penerimaan dari denda pelanggaran eksploitasi hutan; penerimaan dari jenis tumbuhan dan satwa liar, yang dilindungi undangundang, yang diambil dari alam maupun penangkaran; dan penerimaan pelayanan dokumen angkutan hasil hutan. 
Pembagian penghasilan dari Sumber Daya Hutan (SDH) mengacu kepada UndangUndang Nomor 33 tahun 2004 tentang Perimbangan Keuangan antara Pemerintah Pusat dan Pemerintah Daerah. Pada pasal 14 dinyatakan bahwa Pembagian Penerimaan Negara yang berasal dari Sumber Daya Alam (SDA) ditetapkan:

(a) Penerimaan kehutanan yang berasal dari penerimaan luran Hak Pengusahaan Hutan (IHPH) dan Provisi Sumber Daya Hutan (PSDH) yang dihasilkan dari wilayah daerah yang bersangkutan dibagi dengan imbangan 20\% (dua puluh persen) untuk pemerintah dan $80 \%$ (delapan puluh persen) untuk daerah.

b. Penerimaan Kehutanan yang berasal dari Dana Reboisasi dibagi dengan imbangan sebesar 60\% (enam puluh persen) untuk Pemerintah dan $40 \%$ (empat puluh persen) untuk Daerah.
Berdasarkan peraturan di atas, sudah ada gambaran tentang pembagian beban biaya dalam pembangunan $\mathrm{KPH}$ maupun pembagian hasil dari SDH. Dalam kajian ini belum sampai kepada tarap menilai efisiensi biaya dan internalisasi eksternalitas.

\section{Partisipasi:}

aturan

keterwakilan

Pengaturan partisipasi dapat dilihat pada Peraturan Kepala Badan Planologi Nomor SK.80/VII-PW/2006 tentang Pedoman Pembangunan Kesatuan Pengelolaan Hutan (KPH) Model. Pada pasal 7 dinyatakan bahwa Rancangan Pembangunan KPH Model disusun dengan menggunakan metode modelling dengan pendekatan metode berpikir sistemik, dan elibatkan pihakpihak terkait (stakeholder) utama, dan melibatkan pakar relevan. Pada pasal 8 menyatakan bahwa pelibatan stakeholder utama 
didasarkan pada strateg pencapaian tujuan yang merupakan kewenangan berbagai stakeholder sehingga perlu adanya pembagian peran, dimana pembagian peran diarahkan untuk dapat mewujudkan mobilisasi sumberdaya pembangunan $\mathrm{KPH}$.

\section{Mencermati}

bunyi peraturan di atas, dapat dinilai bahwa semangat menggalang partisipasi dari berbagai stakeholder dalam pembangunan $\mathrm{KPH}$ sudah dinyatakan secara formal. Kemudian pencermatan terhadap dokumen proses-proses pembentukan $\mathrm{KPH}$ Model di bebagai tempat, maupun kegiatan yang penulis langsung ikuti, langkah-langkah partisipatif ini memang telah dilakukan. Contohnya, dalam perumusan rancang bangun $\mathrm{KPH}$ Model di Provinsi Kepulauan Riau, dilakukan workshop yang melibatkan berbagai instansi serta unsur terkait, mulai dari perwakilan Kementerian
Kehutanan, Unsur Perguruan Tinggi, Dinas Provinsi, Bapeda, BPPN, Dinas Kabupaten, Camat hingga Kepala Desa. Demikian juga dalam proses penyusunan rencana aksi.

3. Informasi: akses, cakupan, kualitas, transparansi.

Pada tataran peraturan, Bangsa Indonesia saat ini patut bergembira karena telah telah diterbitkan Undang-Undang Nomor 14 tahun 2008 tentang Keterbukaan Informasi Publik. Undang-undang yang terdiri dari 64 pasal ini pada intinya memberikan kewajiban kepada setiap lembaga publik untuk membuka akses bagi masyarakat untuk mendapatkan informasi publik, kecuali beberapa informasi tertentu. Sebagai penjabaran dari Undang-Undang tersebut, pemerintah telah menerbitkan Peraturan Pemerintah Nomor 61 Tahun 2010 tentang Pelaksanaan UU Nomor 14 Tahun 2008. Pada sektor kehutanan, Kementerian 
Kehutanan telah menerbitkan Peraturan Menteri Kehutanan Nomor P.02 Tahun 2010 tentang Sistem Informasi Kehutanan. Pada tataran implementasi, Kementerian Kehutanan, dinasdinas di tingkat provinsi dan kabupaten, UPT-UPT, dan sejumlah $\mathrm{KPH}$ yang sudah terbentuk umumnya sudah menyediakan sistem informasi melalui situs masing-masing. Guna menyediakan informasi secara nasional, Kementerian Kehutanan telah membuat situs "Media Informasi KPH" dengan alamat

http://www.kph.dephut.go.id/.

Selain itu Kemenhut juga telah mengeluarkan beberapa buku tentang $\mathrm{KPH}$.

Pada level pengelolaan hutan, hal mendasar dari keberadaan $\mathrm{KPH}$ adalah akan lebih memastikan diketahuinya potensi hutan, perubahanperubahan yang terjadi maupun kondisi masyarakat yang tergantung pada manfaat sumberdaya hutan. Selain itu, sangat dipahami bahwa berbagai ragam fungsi hutan pada faktanya terletak dalam hamparan bentang alam yang secara manajemen lebih memungkinkan efisiensi dan efektivitas pengelolaan hutan lestari. Dalam hal ini KPH dapat dimaknai sebagai pihak yang menghimpun informasi sumberdaya hutan untuk melakukan pengelolaan hutan yang saat ini tidak dijalankan secara langsung oleh Kementerian Kehutanan atau Dinas Kehutanan (Kartodihardjo et al, 2011).

Dengan demikian pada tataran normatif maupun implementasi, pemeritah sedang mengarah kepada menyajikan berbagai informasi yang dapat diakses langsung oleh publik. Sedangkan pada level tapak, keberadaan $\mathrm{KPH}$ menjadi faktor pemungkin bagi terkumpulnya informasi yang akurat tentang 
kondisi hutan, kondisi

Adapun terkait keadilan masyarakat, serta dinamika yang menyertainya.

\section{Pembangunan} keadilan dan

Keahlian: pembangunan SDM dan modal sosial.

Peraturan Kepala Badan Planologi Nomor SK.80/VIIPW/2006 Pasal 14 menyatakan bahwa organisasi

$\mathrm{KPH}$ merupakan unit organisasi yang diisi oleh personal (SDM) yang memiliki kompetensi sesuai bidang yang diperlukan. Pengisian personil (SDM) antara lain diarahkan untuk lebih mendayagunakan rimbawan / tenaga kehutanan (lulusan pendidikan menengah dan tinggi jurusan kehutanan). Bunyi peraturan tersebut menekankan kepada pendayagunaan SDM yang kompeten di bidangnya, yakni rimbawan / tenaga kehutanan (lulusan pendidikan menengah dan tinggi jurusan kehutanan). dan efisiensi pembangunan modal sosial, dapat dianggap telah menjadi komitmen baru pemerintah yang tercermin dari kebijakan-kebijakannya.

Misalnya dalam melakukan penilaian kinerja pengelolaan hutan oleh unit manajemen, salah satu kriteria SFM adalah kelestarian aspek sosial. Namun demikian, sejauhmana akurasi dan keseriusan implementasi dari peraturan dan kebijakan pemerintah ini, masyarakat dapat melakukan evaluasi dan penilaian dari waktu ke waktu.

5. Proses perencanaan dan pengelolaan: penetapan prioritas, pembuatan keputusan, koordinasi, dan umpan balik perbaikan.

Proses perencanaan dan pengelolaan akan menjadi bagian dari tugas organisasi pengelola $\mathrm{KPH}$. Tugas ini dinyatakan pada Peraturan Pemerintah Nomor 6 Tahun 2007 pasal 13 yang berbunyi "Kepala KPH menyusun 
rencana pengelolaan hutan berdasarkan hasil kegiatan inventarisasi hutan, dengan mengacu pada rencana kehutanan nasional, provinsi, maupun kabupaten/kota dan dengan memperhatikan aspirasi, nilai budaya masyarakat setempat, serta kondisi lingkungan."

Perencanaan yang dibangun berdasarkan basis data yang lengkap dan akurat hasil inventarisasi hutan di tingkat tapak, memberi peluang besar untuk tercapainya tujuan-tujuan dari perencanaan itu sendiri. Namun demikian belum dapat diketahui hal-hal yang berkaitan dengan penetapan prioritas, pembuatan keputusan, koordinasi, dan umpan balik perbaikan, karena hal ini baru akan terlihat bila unit-unit $\mathrm{KPH}$ sudah memiliki dokumen perencanaan dan telah beroperasi.

\section{KESIMPULAN}

Berdasarkan hasil kajian terhadap konsepsi $\mathrm{KPH}$ dan proses-proses awal implementasinya, dapat ditarik kesimpulan sebagai berikut:

1. Telah tergambar adanya kejelasan peran dan kewenangan di antara instansi pemerintah (pemerintah, pemerintah daerah) dengan pengelola $\mathrm{KPH}$.

2. Dalam hal keuangan, pembagian pembiayaan dan penghasilan dari SDH untuk pusat dan daerah telah diatur dalam Undang-Undang Nomor 33 Tahun 2004 dan Peraturan Pemerintah Nomor 6 Tahun 2007.

3. Dalam hal partisipasi, peraturan-peraturan yang ada sudah memberikan ruang partisipasi yang cukup luas bagi multipihak, mulai dari tahap pembangunan konsep, penyusunan peraturan, hingga implementasi $\mathrm{KPH}$. 
4. Dalam hal keterbukaan informasi, telah ada UndangUndang Nomor 14 Tahun 2008 tentang

Keterbukaan Informasi Publik. UndangUndang ini telah dijabarkan ke ke dalam Peraturan Pemerintah dan Peraturan Menteri. Dalam pengelolaan hutan, keberadaan $\mathrm{KPH}$ menjadi faktor pemungkin bagi terkumpulnya informasi yang akurat tentang kondisi hutan, kondisi masyarakat, serta dinamika yang menyertainya.

5. Dalam hal pembangunan kapasitas para pihak, secara konseptual telah diatur pendayagunaan SDM yang kompeten di bidangnya, demikian juga dalam pembangunan modal sosial.

6. Dalam proses perencanaan dan pengelolaan, instansi pemerintah dan $\mathrm{KPH}$ menjadi pelaku utama, namun dengan memperhatikan aspirasi, nilai budaya masyarakat setempat, serta kondisi lingkungan.

Dengan demikian maka baik secara konseptual maupun berdasarkan proses-proses pembangunannya, dapat dikatakan bahwa $\mathrm{KPH}$ telah mengakomodir sebagian besar nilai-nilai Good Forestry Governance. Oleh karena itu melalui kelembagaan $\mathrm{KPH}$, diharapkan dapat terwujud tata kelola hutan Indonesia yang lebih baik. Namun demikian kesimpulan ini tidak menapikan kemungkinan ditemukannya sejumlah kelemahan yang akan diketahui pada tahap implementasi lebih lanjut.

\section{DAFTAR PUSTAKA}

AusAID (2000). Good Governance: Guiding Principles for Implementation. Canberra: The Australian Government's Overseas Aid Program (AusAID)

Bank Dunia. 2009. Roots for Good Forest Outcomes: An Analytical Framework for 
Governance Reforms. Report No. 49572-GLB. Washington, DC: The International Bank for Reconstruction and Development / The World Bank.

[Ditjenplanhut] Direktorat Jenderal Planologi

Departemen

Kehutanan. 2009. Sekilas tentang $\mathrm{KPH}$ dan Perkembangan Pembangunan $\mathrm{KPH}$. [Terhubung Berkala]. www.dephut.go.id [18 Jan 2010]

Dunn, W. 2000. Pengantar Analisis Kebijakan Publik. Terjemah. Edisi kedua. Yogyakarta: Gadjah Mada University Press

[ICCON] Information and Communication Center on Nusa Tenggara. 2006. Masyarakat Adat dan Pembangunan Kehutanan. [Terhubung Berkala] http://www.infonusra.org /html/Berita/Masyarakat Adat dan Pembangunan Kehutanan.htm. [19 Des 2009] Kartodihardjo H, Nugroho B, Putro HR. 2011. Pembangunan Kesatuan Pengelolaan Hutan (KPH): Konsep, Peraturan Perundangn dan Implementasi. Jakarta: Kementerian Kehutanan RI.

Mayers, S. S. Bass, dan D. Macqueen. 2002. The Pyramid: A Diagnostic and Planning Tool for Good
Forestry Governance. London: International Institute for Environment and Development (IIED)

Peraturan Menteri Kehutanan Nomor P.6/Menhut-II/2009 tentang Pembentukan Kesatuan

Pengelolaan Hutan.

Peraturan Kepala Badan Planologi Kehutanan Nomor SK. 80/VII-PW/2006 tentang Pedoman Pembangunan KPH Model

Peraturan Pemerintah Nomor 6 Tahun 2007 tentang Tata Hutan dan Penyusunan Rencana Pengelolaan Hutan serta Pemanfaatan Hutan

Pratikno. 2005.

Good Governance dan Governability. Jurnal IImu Sosial dan Ilmu Politik, Volume 8, Nomor 3, Maret 2005 (231248).

Undang-Undang Nomor 33 tahun 2004 tentang Perimbangan Keuangan antara Pemerintah Pusat dan Pemerintah Daerah Undang-Undang Nomor 41 Tahun 1999 tentang Kehutanan 